\title{
Energy supply in the Khabarovsk territory: intra-regional differentiation and problems of budgetary support
}

Olga Dyomina*, and Svetlana Naiden, Economic Research Institute of Siberian Branch of the Russian Academy of Sciences, Khabarovsk, Russia

\begin{abstract}
The article is devoted to measuring solvable demand of population for energy supply services and the level of budgetary guardianship in Khabarovsk Krai. The authors show the differentiation in availability of energy supply services for consumers, explained by the geographical contrasts and existing system of settlement. There are two sources of energy supply in Krai: "Far Eastern Generating Company" (AO "DGK") and objects of public energetics. The population pays for only a part of actual producers' costs for energy supply services; the remaining part is compensated by the state through budgetary means. There are two ways to compensate high tariffs on energy supply for population: subsidies and privileges for consumers and subsidies for producers. The population that gets its energy from AO "DGK" pays for energy supply services almost entirely, while population that uses the services of public energetics pays only partially, with the state taking the burden upon itself to compensate the producers' costs. In case of transitioning to full compensation, the scale of social budgetary support will increase significantly, which contradicts the logic of institutional transformation, aimed at lowering the financial burden of the state.
\end{abstract}

\section{Introduction}

Organizational and technological specifics of electricity and heat energy markets expect the necessity of state regulation of these markets to protect consumers' rights. There are two ways to regulate: introducing rules that determine the producers' behavior (conditions for entering the market and principles of pricing) or creating the conditions for stimulating the competition in the electricity and heat energy markets (removing barriers on entering, limiting concentration and vertical integration) [1-3]. There are many tools of state regulation as part of the first approach but they all pursue the same goal: protect the consumers (prices are as close to the marginal costs as possible and provide only normal gain for the producer), stimulate the efficiency [4, 5].

Since electricity and heat supply satisfy basic needs, the access to the services is necessary for all groups of population in accordance to the concept of public utility [6]. The state achieves this goal through regulating tariffs on electricity and heat energy using

* Corresponding author: demina@ecrin.ru 
different measures of consumer support depending on the level of income, while taking into account market limitations and monopoly nature of production and provision of vital services.

The accessibility and consumption of energy supply services is especially important for the population of harsh Russian Far East, removed from transport arteries and economically developed centers of the country. The following study emphasizes measuring the solvable demand of population and level of budgetary guardianship while realizing state policy of transition to full compensation of production costs by the population.

The level of budgetary guardianship [7] is state's share (via privileges and subsidies) in paying for energy supply services consumed by the population. The scale of budgetary guardianship depends on the dynamics of tariffs on electricity and heat energy, purchasing power of population and existing structure of population that requires social support.

The subject of the study is Khabarovsk Krai that has characteristics typical for the region as a whole. For example, the Krai has both southern and northern regions that differ significantly by level of economic development, rate of distribution of public utilities and quality of life, including cost and availability of energy supply services. At the same time, the issues of lowering the differentiation of tariffs on energy resources and of determining the necessary scale of budgetary support remain.

\section{Characteristics of consumers and producers of energy supply services}

There is 1330.1 thousand people living in Khabarovsk Krai. The significant area of Krai (787.6 thousand sq $\mathrm{km})$, the spread from north to south $(1800 \mathrm{~km}$, from west to east $125-750 \mathrm{~km})$ and the uneven distribution of natural resources determined the existing system of settlement and focal nature of economic activity [8]. Due to economic transformations of 1990s the constant population of Krai decreased by $16.7 \%$ in 25 years [9]. Due to natural decline and migration outflow, the distribution of population changed. Nowadays $65 \%$ of the population resides in two large cities: Khabarovsk and Komsomolskon-Amur; $10 \%$ - in district centres, $25 \%$ - in small settlements far removed from one another.

Main labour markets concentrate in the south where the majority of population lives, but higher income is formed in the north where processing industry is located. The range of variation in salary is on average 3.5 times, in public utilities cost -5.5 times.

Despite the decline in population, the total housing area increased 2.1 times and the housing area per capita - 1.6 times, thanks to new construction in Krai. The 2 times regional difference between maximal (33.8 square meters per capita in Okhotsky District) and minimal (17.7 square meters per capita in Tuguro-Chumikansky District) housing availability, however, remains. The maintenance of housing does not exceed $80 \%$. Low occupancy of the territory and low population density together with harsh climate require longer network, which increases the costs of energy supply, maintaining and exploiting infrastructure, delivery of water and heat. As a result, central heating is developed in cities only, while other settlements rely on local sources.

Climatic specifics contribute to regional differentiation of energy supply conditions: the heating season in the south lasts 7 month, in the north -9 month.

In 2016, the total output of electricity sources in Khabarovsk Krai was 2408 MW, total energy produced - 8724.7 million $\mathrm{kWh}$; total output of heat sources - 9890.2 Gcal per hour, total heat energy - 13.9 million Gcal.

The main producers of electricity and heat energy in Krai are thermal power plants and boilers of "Far Eastern Generating Company" (AO "DGK") that provide 98\% of electricity and $77 \%$ of heat produced in Krai. Large systems of central heating exist only in 4 cities: 
Khabarovsk, Komsomolsk-on-Amur, Amursk, Nikolayevsk-on-Amur. Total output of 8 thermal power plants is 2.2 thousand MW (92\% of electricity) and 7 thousand Gcal per hour $(70 \%$ of heat). The remaining demand for electricity and heat is covered by local energy supplies.

Krai has considerable reserves of energy power since current production volumes exceed total demand for electricity and heat. However, the energy supply system features disproportion between reserves and network by different local nodes. Besides, there are limitations in reliability of energy supply due to high deterioration of equipment on power plants (60-90\%), electrical substations below $220 \mathrm{~kW}(67-87 \%)$ and power lines below $110 \mathrm{~kW}(57-59 \%)$.

\section{Tariff policy and regulation on the energy supply market}

The tariffs on electricity and heat in Khabarovsk Krai are regulated by the state and are determined based on the producers' costs. The level of costs for AO "DGK" and objects of public energetics differs on average 5 times for electricity, 2 times for heat. The significant difference exists between objects of public energetics -9 times between maximal and minimal costs for producers of electricity, 10 times - for producers of heat (Fig.1). As a result, the difference falls on consumers, which conflicts with the principles of market competition and social justice.

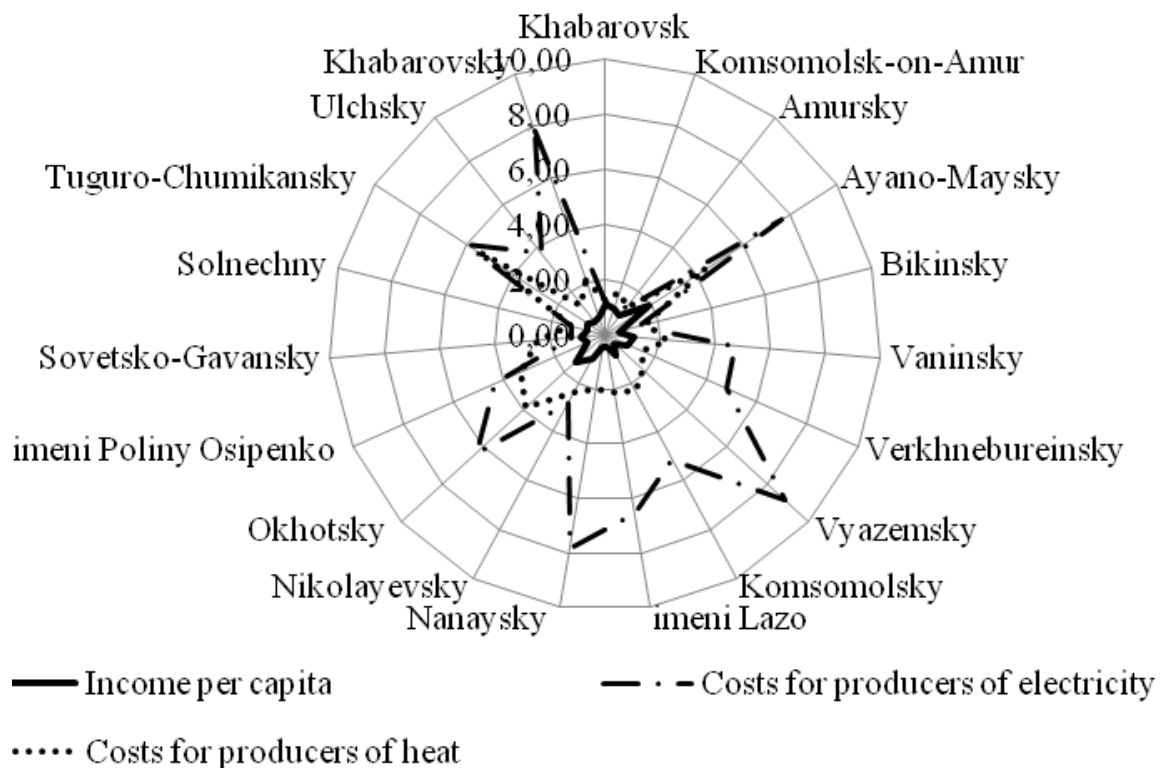

Fig. 1. Differentiation of producers' costs and consumers incomes, times by average

The population is one of the main consumers of electricity and the largest consumer of heat in Khabarovsk Krai. It consumes $14 \%$ of total electricity and $58.3 \%$ of total heat provided in Krai. However, the purchasing power of the population is not as various as the differentiation of producers' costs. Income in the north, where tariffs are higher, is limited by narrow local labour market, unlike more developed southern districts of Krai. This causes the necessity of state's participation in providing the availability of vital services including energy supply. 
The share of population expenses on public utilities in Krai is $10.4 \%$, which is slightly higher than country average in 2016. The share of expenses on energy supply in total expenses on public utilities varies from $33.5 \%$ in Khabarovsk (the south), where energy is provided by AO "DGK" and income is higher, to $94 \%$ in Tuguro-Chumikansky District (the north), where energy is supplied by local providers and income is limited for both the population and the budget. The average share of expenses on energy in Krai is $42 \%$.

There are two ways to compensate high tariffs on energy supply for population: subsidies and privileges for consumers and subsidies for producers. Subsidies and privileges for consumers are aimed at certain groups, while subsidies for producers allow lowering the tariffs for all population groups regardless of their income.

Khabarovsk Krai uses the first approach: the state regulates producers' behaviour directly. Federal Antimonopoly Service of Russia establishes the ultimate tariffs on electricity and heat. The Krai sets maximal growth rate of total cost of public utilities by each city and settlement. Annually, the Governor of Khabarovsk Krai establishes maximal tariff on heat.

Thanks to the state policy of limiting the growth of prices, compensation of difference between economically justified tariff and accessible tariff, the population pays only part of total cost for energy supply services [10].

\section{Compensating producers' costs: population contribution and state guardianship}

The population that gets its energy from AO "DGK" pays almost total cost of electricity and heat energy - on average $79 \%$ and $84 \%$ respectively (Fig.2). The compensation of producers' costs happens thanks to cross-subsidizing between consumer groups - for electricity, between energy types - for heat. There is slow decline in crosssubsidizing between energy types.

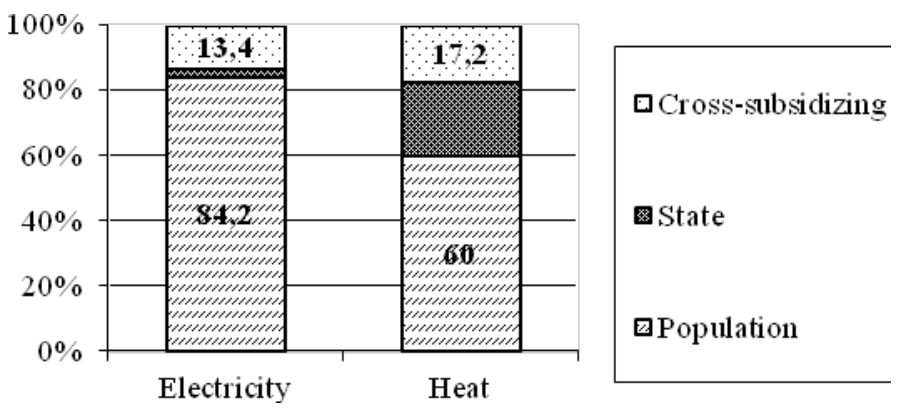

Fig.2. The structure of payment for energy for AO "DGK" consumers

For consumers that receive energy from local suppliers the level of compensation is on average $15 \%$ for electricity, $64 \%$ - for heat (Fig.3). There is significant variance in levels of compensation inside this group: from 12 to $38 \%$ for electricity, form 22 to $95 \%$ for heat.

Where public energetics exists, the producers are given compensation out of Krai budget to cover the difference between actual costs and lowered population tariffs. The volume of budget support in 2015-2018 increased 1.5 times and reached 4.13 billion rubles, majority of which is aimed at compensating population tariffs on heat. 


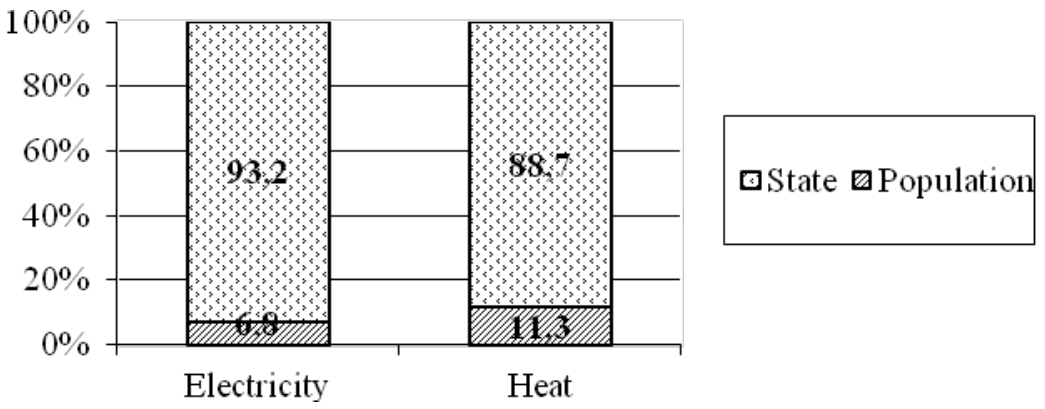

Fig.3. The structure of payment for energy for local suppliers consumers

Where AO "DGK" is active, the population carries the burden of paying for electricity itself. In territories with public energetics, where only $2 \%$ of the population lives, the state takes the burden on itself, providing $66 \%$ of total resources aimed at supporting the population with paying for electricity supply (privileges and subsidies together with paying producers for compensating for privileged tariffs).

A similar situation exists where heat energy is concerned. Here, the state provides $60 \%$ of means of support where public energetics exists (privileges and subsidies together with paying producers for compensating for privileged tariffs).

In 2016, 4.5 billion rubles were spent on social support in housing and public utilities in Khabarovsk Krai, out of which 975 million rubles were subsidies for low-income population and 3.5 billion rubles - compensation for preferential groups.

In case of transitioning to full compensation from $85 \%$ to $100 \%$ the share of state guardianship in Krai will increase from $9 \%$ to $12 \%$ from total cost of public utilities. Considering that $13 \%$ of Krai's population lives below poverty line and $21 \%$ is in a preferential group, increasing the burden on household budgets even by one percentage point would require increasing the share of state expenses by two percentage points.

\section{Conclusions}

The processes of differentiation that worsen stratification of population and increase level of budgetary guardianship in Krai persevere despite transformations and improvements in energy supply.

The state's attempts to shift the burden of public utilities costs, including energy supply, on population remain ineffective. The only change is the direction of budgetary resources.

Any changes of tariff policy when there is a system of objective limitations on income growth, on keeping the system of state privileges, on adequate tools of keeping the growth of producers' costs in check, will inevitably lead to the increase in state's expenses on supporting population's purchasing power. The scale of such support in Khabarovsk Krai is explained not by high tariffs and low population income, but high costs of producing public energy.

\section{Acknowledgements}

The reported study was funded by RFBR according to the research project №. 17-3200013-OGN 


\section{References}

1. P.L.Joskow. Regulation of Natural Monopolies. Handbook of Law and Economics. Vol. 2, pp. 1227-1348 (2007)

2. S.Stoft Power System Economics: Designing Markets for Electricity. IEEE Press. 468 p. (2002)

3. Coming in from the Cold. Improving District Heating Policy in Transition Economies OECD, IEA, 264 p. (2006)

4. M.A.Deryabina Reforming of natural monopolies: theories and practice. Voprosy ekonomiki. Vol. 1, pp.102-121 (2006)

5. N.I.Ayzenberg, M.A.Kiseleva, V.I.Zorkaltsev. Models of Imperfect Competition in Analysis of Siberian Electricity Market. Journal of the New Economic Association. 2 (26), pp. 264-269 (2013) (in Russian)

6. http://reference.findlaw.com/lawandeconomics/5400-regulation-of-naturalmonopoly.pdf (Accessed at 11.05.2018)

7. A.Ya.Rubinshtein On the Theory of Markets of "Patronized Goods". Moscow: Institute of Economics RAS (in Russian). (2008)

8. Economy of regions. Khabarovsk Krai / Edited by Academician P.A. Minakir ; Russian Academy of Sciences, Far Eastern Branch, Economic Research Institute. Khabarovsk: ERI FEB RAS, 400 p. (2014)

9. Ye.L.Motrich, S.N.Naiden. Migratory processes in the socioeconomic development of the Far East. Studies on Russian Economic Development 26(5), pp. 491-498 (2015)

10. O.V.Dyomina The District Heating Regulation in Russia: Local Markets' Reaction. Spatial Economics 3, 62-82 (2017) (In Russian). DOI: 10.14530/se.2017.3.062-082 